\title{
Optimization of Estrogenic Activities of Kebar Grassextract (Biophytum Petersianum) on White Female Mice (Mus musculus)
}

\author{
Mulyati Effendi, Prasetyorini, Sara Azzahra
}

\begin{abstract}
Menopause occurs caused bythe decline of estrogen hormone due to the depletion of the ovarian egg. As estrogen levels decrease, the risk of osteoporosis, bone fractures, heart disease and even cancer increase. The kebar grass (Biophytum petersianum), which has long been used as atraditional fertility medicine by Papuans, is suspected to have anestrogenic activity. The purpose of this study was to determine the estrogenic activity of kebar grass extract on female mice (Musmusculus). Five experimental female mice groups were used in this study. Each group consisted of 5 mice.The negative control group was administered with aquadest; the positive control was administered withesthero conjugated estrogen $0.625 \mathrm{mg}$; the first group (P1) was administered with 3\%kebargrass extract; the $(P 2)$ group was administered with $5 \%$ kebar grass extract and the (P3) was administered with 10\% kebar grass extract. The experiment was carried out for 7days. The results of the study showed that the kebar grass extract has an estrogenic effects on female mice include to shorten the estrous cycle, prolong the estrous phase, improving the vascularity of ovary and uterus, and increase the weight of ovary and uterus. The highest estrogenic activity was reached when the mice was administered with $10 \%$ kebar grass extract.
\end{abstract}

Index Terms: Kebar grass, estrogenic activity, white female mice.

\section{INTRODUCTION}

The psychological and physical function decline in are closely related to the aging process in human body. In women, the aging process was triggered by the lack of estrogen production in the ovarium during menopause or late reproductive phase [1]. Menopause is the normal, natural transition in life that begins between the ages of 35-55. During this time, fertility declines, the eggs are depleted, the ovaries get smallerand stop producing the hormones estrogen and progesterone that control the menstrual cycle [2].

The subside of estrogen production result in various common syndromes such as hot flushes filling, sweating profusely, insomnia, depression and irritability. The lack of estrogen also leads to osteoporosis, heart disease and even cancer risk [3]. The estrogen replacement therapy or hormone replacement therapy (HRT) using synthetic hormone such as

Revised Manuscript Received on April 25, 2019.

Mulyati Effendi, Department of Biology, Pakuan Bogor University, 16143, Indonesia.

Prasetyorini, Department of Biology, Pakuan Bogor University, 16143, Indonesia.

Sara Azzahra, Department of Biology, Pakuan Bogor University, 16143, Indonesia. estradiol was the common method used to treat estrogen deficiency, but the long-term use of synthetic estrogens associated with various side effect such as hyperplasia, uterine cancer, and breast cancer [4].

The use of plant materials containing phytoestrogens is an option that can be used as a substitute for synthetic estrogens and it is believed that natural estrogens are safer because they carry less risk of bleeding and have fewer side effects [5]. The kebarwas known by local Papuan peopleas a medicine to enhance women fertility. The local name of this grass is banondite which means many children. Previous research revealed that the kebar grass contain the fertility enhancing active compounds [6]. Phytochemical study of Sembiring and Darwati (2014) showsthat kebar grass contains alkaloids, saponins, tannins, phenolic, flavonoids, triterpenoids, steroids and glycosides [7].

The study of [8] had proved that the infusion of grass at a concentration of $5 \%$ significantly increase the spermatogenesis activity. However, this study onlyrevealthe activity of spermatogenesis, while for oogenesis has not been done.

According to research of [9], administration of 0.135 $\mathrm{mg} / \mathrm{g}$ body weightof kebar grass extractto white micefemales can prolong estrus length, increase the number of embryo, increase body weight, the number of child and a weight of newborn child.

This study was conducted to determine the the activity of kebar grass extract to the estrogenic activity, duration of the estrous cycle, duration of estrous phase, vascularity and ovarian and uterine weight in female white mice. A research on the activity of grass kebar extractin the form of liquid preparations in the hope that it can shorten the estrous cycle, extend the estrous phase, vascularization and increase ovarian weight and uterine weight with dose reference. The benefits of the results of this study can be used in community service as information about plants that estrogen as estrogenic to the community, especially mothers who have stepped on the age of $40-50$ years.

\section{MATERIAL}

\section{A. Apparatus}

Juicer, analytical scales, funnel, dropper, sonde apparatus, beaker glass, measuring cup, spatula, plastic tub, mice feeding bottle, syringe (mL), microscope, object glass, cotton bud and dissecting kit. 


\section{B. Chemicals}

Physiological $\mathrm{NaCl}$, giemsa dye, aquadest, esthero conjugated estrogen $0.625 \mathrm{mg}$,

Ketamin xylazin and methanol 10\%, and other supporting materials such mice forage.

\section{Animal}

Twentyfive female mice Mus musculusaged 2-3 months, weighed 20-25 g were acclimatized for 1 week. All the micehad free access to tap water and standard pellet diet. The acclimatization procedure wasperformed according to the international guidelines for laboratory animal use and care. After 1 week, the mice were divided into 5 treatment group that are $\mathrm{K}-, \mathrm{K}+, \mathrm{P} 1, \mathrm{P} 2$, and $\mathrm{P} 3$. Each group consisting of five mice.

- (K-) negative control, administered with aquadest

- $(\mathrm{K}+)$ positive control, administered withesthero conjugated estrogen $0.625 \mathrm{mg}$

- (P1) administered with kebar grass extract at concentrationof $3 \%$.

- (P2) administered with kebar grass extract at concentration of $5 \%$.

- (P3) administered with kebar grass extract at concentration of $10 \%$

To stimulate whitten effect or synchronous estruson female mice, the cage of male mice was placed next to the female cage. administered for 3 days, this method is done by cage male mice placed on the cage of female mice.

\section{METHOD}

\section{A. Extraction Procedure}

Thekebar grass was sorted, cleaned, washed under running tap water and dried in room temperature. The grass (500 gr) was grinded using juicer machine then filtered using Whatman paper. The extract obtained was measured using measuring cup [10].

\section{B. Determination of Estrogenic Activity}

The parameters measured to determine the estrogenic activity of kebar grass were the duration time of estrous phase, the ovary and uterus vascularity and the weight of ovary and uterus.

\section{Measurement of Estrus Cycle Time}

Estrus cycle time was measured by observing physical change of vaginal mice (vaginal preparation method/vaginal smear).Preparation of twice daily in the morning and at night during treatment and after giving each treatment for 7 days, while looking at macroscopic signs of estrus covering the condition of the vulva and vagina [11]..Observing the length of the estrous cycle (proestrus, estrus, metestrus and diestrus) can be investigated by calculating the time (hour) of the estrous cycle of the mouse starting from the end of the estrous phase (the presence of cornification cells and the presence of leukocytes) up to the early signs of the estrous phase characterized by the presence of chromosomal epithelial cells).

\section{Ovary and UterusVascularity}

The ovary and uterusvascularity wasobserved by dissection methods.Dissection process was performed to the estrous phase mice during treatment and after treatment, then dissected for ovaries and uterus removed, mucosal colors were seen in the ovaries and uterus of mice.Assessment and observation of vascularization is expressed by scoring, in accordance with modification of the Rugh method [12]

\section{E. Measuring the Ovary and Uterus Weight}

The weight of ovaries (left and right ovaries and uterine were measured separately. The ovary and uterus were taken from the mice, then washed using physiologicalNaCl, placed on filter paper and weighed in wet condition using analytical balance [13]

\section{RESULTS AND DISCUSSION}

\section{A. Kebar Grass Extract}

The 62 mLconcentrate extract (100\%)was obtained from $500 \mathrm{~g}$ fresh kebar grass. The concentrate extract then diluted with aquadest to obtain 3\%, 5\% and 10\% of kebar grass extract solution.The effects of kebar grass extract administration to the estrus cycle in female mice during and after treatment were shown in Table 1 and Table 2.

Table 1. Female Mice Estrus Cycle During Administration of Kebar Grass Extra

\begin{tabular}{|c|c|c|c|c|c|}
\hline \multirow{2}{*}{ Repeating } & \multicolumn{5}{|c|}{ Estrus Cycle Period (hours) } \\
\cline { 2 - 6 } & $\mathbf{K}-$ & $\mathbf{K}+$ & $\mathbf{P 1} \mathbf{3 \%}$ & $\mathbf{P 2} \mathbf{5 \%}$ & $\mathbf{P 3 ~ 1 0 \%}$ \\
\hline $\mathbf{1}$ & 36 & 48 & 48 & 60 & 0 \\
\hline $\mathbf{2}$ & 96 & 0 & 0 & 0 & 0 \\
\hline $\mathbf{3}$ & 120 & 48 & 84 & 36 & 0 \\
\hline $\mathbf{4}$ & 132 & 36 & 36 & 60 & 0 \\
\hline $\mathbf{5}$ & 96 & 0 & 60 & - & - \\
\hline Sum & 480 & 132 & 228 & 156 & 0 \\
\hline Average & $96^{\mathrm{c}}$ & $26,4^{\mathrm{ab}}$ & $45,6^{\mathrm{bc}}$ & $39^{\mathrm{b}}$ & $0^{\mathrm{a}}$ \\
\hline
\end{tabular}

Table 2. Female Mice Estrus Cycle After Administration of Kebar Grass Extract

\begin{tabular}{|c|c|c|c|c|c|}
\hline \multirow{2}{*}{ Repeating } & \multicolumn{5}{|c|}{ Length of Estrus Cycle (hours) } \\
\cline { 2 - 6 } & K- & K+ & P1 3\% & P2 5\% & P3 10\% \\
\hline $\mathbf{1}$ & 108 & 48 & 72 & 108 & 48 \\
\hline $\mathbf{2}$ & 144 & 108 & 72 & 24 & 24 \\
\hline Sum & 252 & 156 & 144 & 132 & 72 \\
\hline Average & 126 & 78 & 72 & 66 & 36 \\
\hline
\end{tabular}

Data presented in Table 1 showing that, based on the Duncan test, the administration ofkebar grass extract atvarious concentrations has avery significant different effect in shortening the estrous cycle time $(\mathrm{P}<0.01)$. The most effective dose of kebar grass extract to shorten estrus cycle period was $5 \% \quad(\mathrm{P} 2)$,but it's still longer than the administration ofpositive control $(\mathrm{K}+)$. Increasing the dose to $10 \%$ caused estrus phasecontinuewithout pause.

The development and ability of the ovaries to produce the estrogen hormone can beseen indirectly through the estrogenic activityon the changes of vaginal epithelial cytology.The results of this study prove that administration of kebar grass extract can shorten the length 
of the estrous cycle of female mice.

Table 2 shows that there was a decrease in the length of the estrus phase that occurred in all treatments. Aquadest dministration as a negative control resulted in the longest estrus phase duration among the other treatments, which was reach 126 hours, while administration of $10 \%$ (P3)kebarcould shorten the length of estrus cycle to 36 hours. grass extract still showed the longest estrus phase with length of 36 hours. Positive control resulted in an estrus phase time of 90 hours, which was shorter than the administration of with a concentration of $3 \%(\mathrm{P} 1)$ and a concentration of $5 \%$ (P2) each produced an estrus length of 96 hours and 102 hours. These results prove that administration of biophytumpetersianum is still giving an estrogenic effect even though after 7 days the treatment is stopped.

This results probably due to the presence of secondary metabolites contained in the grass kebar. According to the research [13], kebar grass plants contain chemical compounds class of steroids and saponins. Saponins are the basic ingredient for the synthesis of steroid hormones (gonadotropic).Estrogen is classified as a steroid hormone that has $18 \mathrm{C}$ atoms and one of the sex hormones that plays an important role especially in women. The active compound of flavonoids found in the turmeric grass can bind to the estrogen receptor $(\mathrm{ER} \alpha$ and $\mathrm{ER} \beta)$.

\section{B. Effect of Kebar Grass Extract Administration to theLength of Estrus Phase}

The data obtainedconfirmed that the administration ofkebar grass extract has an effect to the length of estrus phase. Table 3 and table 4 show that the difference of kebar grass extract concentration significantly $(\mathrm{P}<0.01)$ affected the length of estrus phase. The result of Duncan test stated that giving of grass seeds showed very different result with negative control (Iadest), while the positive control (Esthero) gave relative influence with $3 \%$ concentration of P3 concentration (P1), 5\% concentration (P2) ) and concentration of $10 \%$ (P3).So it can be stated that the concentration of $10 \%$ grass (P3) is the most effective concentration, while the $3 \%$ concentration is the most efficient.

According to [14], the average duration of estrous phase in mice is $12-14$ hours, but during long estuary biophytum petersianum to 168 hours ( 7 days), this indicates that the grass extract is capable prolong the duration of the estrous phase.The result of this research shows that the tendency of

increasing the dosage of grass extract will increase the average of estrus length.According to [14], the longer the estrus phase will provide greater opportunities for animals. Table 3. The Length of EstrusPhase During Administration of Kebar Grass Extract

\begin{tabular}{|c|c|c|c|c|c|}
\hline \multirow{2}{*}{ Repeating } & \multicolumn{5}{|c|}{ Length of Phase Estrus (Hours) } \\
\cline { 2 - 6 } & K- & K+ & $\mathbf{P 1 ~ 3 \%}$ & $\mathbf{P 2 ~ 5 \%}$ & $\begin{array}{c}\text { P3 } \\
\mathbf{1 0 \%}\end{array}$ \\
\hline $\mathbf{1}$ & 132 & 120 & 120 & 108 & 168 \\
\hline $\mathbf{2}$ & 72 & 168 & 168 & 168 & 168 \\
\hline $\mathbf{3}$ & 48 & 120 & 84 & 132 & 168 \\
\hline $\mathbf{4}$ & 36 & 132 & 132 & 108 & 168 \\
\hline $\mathbf{5}$ & 72 & 168 & 108 & - & - \\
\hline Sum & 360 & 708 & 612 & 516 & 672 \\
\hline Average & $72^{\mathrm{a}}$ & $141,6^{\mathrm{bc}}$ & $122,4^{\mathrm{b}}$ & $129^{\mathrm{bc}}$ & $168^{\mathrm{c}}$ \\
\hline
\end{tabular}

Table 4. The Length of Estrus Phase After Administration of Kebar Grass Extract

\begin{tabular}{|c|c|c|c|c|c|}
\hline \multirow{2}{*}{ Repeating } & \multicolumn{5}{|c|}{ Length of Phase Estrus (Hours) } \\
\cline { 2 - 6 } & K- & K+ & P1 3\% & P2 5\% & P3 10\% \\
\hline $\mathbf{1}$ & 60 & 120 & 96 & 60 & 120 \\
\hline $\mathbf{2}$ & 24 & 60 & 96 & 144 & 144 \\
\hline Sum & 84 & 180 & 192 & 204 & 264 \\
\hline Average & 42 & 90 & 96 & 102 & 132 \\
\hline
\end{tabular}

ovulate.This will prove that grass kebar essence has estrogenic activity. Based on observations of estrogenic activity of grass cleansing essence after 7 days of treatment, Table 6 shows that there was a decrease in estrus phase time occurring in all treatments. The giving of aquadest as a negative control resulted in the shortest duration of the estrus phase among other treatments of only 42 hours, while giving $10 \%(\mathrm{P} 3)$ grass extract still showed the longest estrous phase of 132 hours.Positive controls resulted in a 90-hour estrus phase, which was shorter than that of $3 \%(\mathrm{P} 1)$ and $5 \%(\mathrm{P} 2)$ concentrations of grass flowered grasses each yielded a duration of 96 hours and 102 hours. This result proves that giving kebar grass still gives estrogenic effect even after 7 days treatment is stopped.

\section{Effect of Kebar Extract Administration to the Vascularity of Ovary and Uterus}

The vascularity of ovary and uterus was affected by administration of kebar grass extract as shown in Table 5 and Table 6. The data showed that the administration of $10 \%$ kebar grass extract increased ovarian and uterine vascularization of mice with an average score of 3 marked with the very red color of ovarian and uterus mucosa.

Table 5. The Ovary and Uterus Vascularity During the Administration of Kebar Grass Extract

\begin{tabular}{|c|c|c|c|c|c|}
\hline \multirow{2}{*}{ Repeating } & \multicolumn{5}{|c|}{ Vascularity Scores Ovaries and uterus } \\
\cline { 2 - 6 } & K- & K+ & P1 3\% & P2 5\% & P3 10\% \\
\hline $\mathbf{1}$ & 3 & 1 & 2 & 2 & 3 \\
\hline $\mathbf{2}$ & 1 & 2 & 2 & 2 & 3 \\
\hline $\mathbf{3}$ & 1 & 1 & 3 & - & - \\
\hline Sum & 5 & 4 & 7 & 4 & 6 \\
\hline Average & $1,67^{\mathrm{ab}}$ & $1,33^{\mathrm{a}}$ & $2,33^{\mathrm{ab}}$ & $2^{\mathrm{ab}}$ & $3^{\mathrm{b}}$ \\
\hline
\end{tabular}

Table 6. The Ovary and Uterus Vascularity After the Administration of Kebar Grass Extract

\begin{tabular}{|c|c|c|c|c|c|}
\hline \multirow{2}{*}{ Repeating } & \multicolumn{5}{|c|}{ Length of Phase Estrus (Hours) } \\
\cline { 2 - 6 } & K- & K+ & P1 3\% & P2 5\% & P3 10\% \\
\hline $\mathbf{1}$ & 3 & 1 & 2 & 1 & 3 \\
\hline $\mathbf{2}$ & 2 & 2 & 2 & 2 & 3 \\
\hline Sum & 5 & 3 & 4 & 3 & 6 \\
\hline Average & 2,5 & 1,5 & 2 & 1,5 & 3 \\
\hline
\end{tabular}

The data obtained by statistical analysis using SPSS 24.The result of analysis showed that giving kebar grass as estrogenik gave no significant effect on ovarian vascularization and uterine mice $(\mathrm{P}>0,05)$. The results of the follow-up test using Duncan test showed that giving concentration of $10 \%(\mathrm{P} 3)$ 


\section{Optimization of Estrogenic Activities of Kebar Grassextract (Biophytum Petersianum) on White Female Mice (Mus musculus)}

concentration of the grass concentration (P3) showed different result with negative control (Iadest).

The results of this test show that giving kebar grass (Biophytum petersianum) has an estrogenic activity that leads to increased secretion of estrogen hormones and will lead to ovarian and uterine vascularization.Vascularization is seen from the color of the mucosa to red due to increased blood vessel activity to the uterus.According to [15] an increase in the number of blood vessels to the uterus due to increased secretion of estrogen. Occurrence of vascularization of the uterus will accelerate blood flow to the uterus.This is reinforced by the opinion of [16], that estrogen can cause an increase in blood flow indirectly because there is also an increase in prostagladin which causes vasodilation of blood vessels in the endometrium and myometrium. After 7 days treatment showed that grass cleansing with $10 \%$ concentration (P3) still got scores with average 3 and was the highest score compared to other concentration and positive control having score score 2.5, whereas negative control had the lowest scoring average score and the equivalent of $5 \%$ concentration of $5 \%$ concentration $(\mathrm{P} 2)$ grass extract, resulting in an average score of 1.5. During 7 days of grass extract giving various concentrations showed the giving of negative control in the form of aquadest resulted the average value of the lowest ovarian weight that is $0,0480 \mathrm{~g}$, meanwhile the highest mean value of weight is on giving kebar grass extract with concentration of $3 \%(\mathrm{P} 1)$ was $0.1088 \mathrm{~g}$. The result of data analysis using SPSS 24 showed that administration of grass kebar extract has no significant effect $(P>0,05)$ on the ovarium weight of female mice.

Result of Duncan test that is giving of grass concentration of $3 \%(\mathrm{P} 1)$ concentration has the same effect with concentration of $10 \%$ (P3). While giving positive control (Esthero) gives the same effect with negative control and grass extract concentration 5\% (P2).From the results of further testing can be seen that giving grass kebar 3\% (P1) and $10 \%$ concentration is the best concentration to increase ovarium mice weight. After 7 days, the treatment of grass extract was carried out again on the weighting of ovarium mice. The result is a decrease in ovary weight after 7 days of treatment at all concentrations except on positive control (Esthero) increased ovarium weight.Positive control (Esthero) gave the highest ovarian weight after 7 days treatment of $0.0698 \mathrm{~g}$, then giving $10 \%$ (P3) grass sari grass gave ovary weight which is not much different from positive control that is $0,0615 \mathrm{~g}$. The lowest ovarian weight after 7 days of admission was negative control of 0.0348 . This result indicates that giving $10 \%$ (P3) of aqueous grass concentration to maintain ovarian weight in mice and its effect is equivalent to positive control (Eshthero) both when treatment is given and 7 days after treatment. For 7 days, the result showed that the grass extract of 3\% (P1) of concentration of parsed grass yielded $0.3213 \mathrm{~g}$ of the uterus, not significant from the $10 \%$ concentration of $10 \%$ concentration of the grass of the concentration of the grass, which resulted in $0.3151 \mathrm{~g}$ uterine weight.Uterine weight data was then analyzed using SPSS 24 statistic, the result is that all treatments gave the same effect $(\mathrm{P}>0,05)$ but giving $3 \%$ kebar grass (P1) yielded the most optimum value compared to other treatment.

The results obtained after 7 days of treatment showed a decrease in uterine weight in all treatments except the provision of positive control (Esthero), while the average weight produced was the lowest on the negative control (Iadest) only $0.1086 \mathrm{~g}$.

Kebar grasses have chemical compounds that can improve reproductive performance [17]. The active compounds that are estrogenic work in the same way as estradiol. After 7 days of treatment still affect vascularization and ovarian-uterine weights. On the positive control and grass extracts of $10 \%$ (P3) concentration of saliva still showed good results from the scores of ovarian and uterine. In the estrus phase the de Graaf follicle enlarges and maturation occurs. This phase of estradiol derived from mature de Graaf follicles, will cause changes in the female reproductive tract and more secrete the esrogen hormone. During the estrous cycle time will occur the process of growth, development and maturation of follicles and produce a number of estradiol from ovaries stimulated by FSH. The shorter the time it takes 1 estrus cycle will speed up follicular maturation. The mature follicle will be stimulated by $\mathrm{LH}$ and ovulation will occur. Unovulated follicles will have atresia [13].

This can be the basis of estrogenic activity in the kebar grass extract which can shorten the estrus cess, extend the estrous phase, vascularization and increase ovarian-uterine weight.Based on the results of [13] research, grass seed karar extract can increase follicular development because it contains saponin which is the basic material for synthesis of steroid hormone that can improve reproduction system performance.

Turmeric grass can be called phytoestrogens because it has estrogenic activity. The mechanism of estrogenic activity can make vascularization and the addition of ovarian-uterine weights are described according to [18], estrogen-targeted tissue is a network of cells containing estrogen receptors.Estrogen secreted by the ovary functions in the enlargement of the uterine organ at puberty because the uterus has a high response to estrogen. According to [19], estrogen receptor (ER $\alpha$ and $E R \beta)$ play a role in maintaining the physiological function of the uterus.The role of ER $\alpha$ is as a marker receptor of estrogenic effects on increased uterine weight and proliferation of luminal epithelial cells, whereas ER $\beta$ is more instrumental in modulating uterine function.

\section{CONCLUSION}

From this research can be concluded:

1. Kebar grass extract an estrogenic activity in female white mice (Mus musculus).

2. The most effective dose of kebar grass extract to shorten estrus cycle, prolonged the duration of estrus phase, increasing vascularization, and increasing the weight of ovaries and uterine weight in female mice was at a concentrationof $10 \%$. 


\section{REFERENCES}

1. A. Proverawat. Menopause dan Sindrome Premenopause. Yogyakarta: Nuha Medika, 2010.

2. T. Nugroho and V. Scorviani. Kamus Pintar Kesehatan. Yogyakarta: Nuha Medika, 2010.

3. A. Proverawati. Menopause dan Sindrome Premenopause. Yogyakarta: Nuha Medika, 2010

4. A. Badzaid. Endokrinologi ginekologi, Jakarta : KSERI, 2003.

5. D. Llewellyn and Jones. Setiap Wanita. Jakarta: Delapratasa Publishing, 2009.

6. B. Sembiring and I. Darwati. "Pemanfaatan Rumput Kebar (Biophytum petersianum)." Warta Puslitbang. Vol. 19, no. 2, pp. 16-18, 2010.

7. B. Sembiring and I. Darwati. "Identifikasi Komponen Kimia Aksesi Rumput Kebar (Biophytum petersianum) Asal Papua dan Jawa." Bulletin Penelitian Tanaman Rempah dan Obat, vol. 25, no. 1, pp. 37-38, 2014

8. P. N. Lefaan. "Pengaruh Infusa Rumput Kebar (Biophytum petersianum) terhadap Spermatogenesis Mencit (Mus musculus).' Jurnal Sain Veteriner. Vol. 32, no. 1, pp. 55-67, 2014.

9. D. P. Sadsoeitoeboen,. Manfaat Ekstrak Rumput Kebar (Biophytum petersianum) Terhadap Penampilan Reproduksi Mencit Putih Betina. Magister Thesis, Institut Pertanian Bogor, 2005.

10. E. W. Martin and E. F. Coock Remington's Praktice Of Pharmacy. Easton Pennsylvalnia: Mack Publishing Company, 1961.

11. E. S. E. Hafez and M. R. Jainudeen, M.R. Hormones, Growth Factors and Reproduction. Philadelphia: Lippincott Williams \& Wilkins, 2000.

12. R. Rugh. The Mouse Reproduction and Development. Menneapolis: Burgess Publishing Company, 1968.

13. M. J. Wajo. Pengaruh Pemberian Ekstrak Rumput Kebar (Biophytum petersianum) melalui Air Minum Terhadap Fertilitas Ayam Buras. Magister Thesis, Universitas Papua, 2005.

14. J. B. Smith and S. Mangkoewidjojo. "Pemeliharaan, Pembiakan Dan Penggunaan Hewan Percobaan Di Daerah Tropis. “ Jakarta: UI Press, 1998

15. W. Manalu and M. Y. Sumaryadi. "Hubungan Antara Konsentrasi Progeteron dan Estradiol Dalam Serum Induk Selama Kebuntingan Dengan Massa Fetus Pada Akhir Kebuntingan." Prosiding Seminar Nasional Sains dan Teknologi Peternakan BPT, pp. 57-62, 1995.

16. E. D. Albrecht and G. J. Pepe. Steroid Endocrinology of Pregnancy.. London: The Global Library of Women's Medicine, 2008.

17. W. Schramm, N. Einer-Jensen, M. B. Brown and J. A. Mc Cracken. "Effect of four primary prostaglandins and relaxin on blood flow in the ovine endometrium and myometrium." Biology of reproduction, vol. 30, no. 3, pp. 523-531, 1984.

18. G. S. Lee, H. J. Kim, Y. W. Jung, K. C. Choi and E. B. Jeung. "Estrogen receptor $\alpha$ pathway is involved in the regulation of Calbindin-D9k in the uterus of immature rats.” Toxicological Sciences, vol. 84, no. 2, pp. 270-277, 2005.

19.J. Frasor, D. H. Barnett, J. M. Danes, R. Hess, A. F. Parlow and B. S. Katzenellenbogen. "Response-specific and ligand dose-dependent modulation of estrogen receptor (ER) $\alpha$ activity by ER $\beta$ in the uterus." Endocrinology, vol. 144, no. 7, pp. 3159-3166, 2003. 